\title{
OPPRESSIVE INDUSTRIES IN THE CONTEXT OF MANAGING AN IMAGE CRISIS
}

\begin{abstract}
The article focuses on the problems of oppressive industries in the context of their vulnerability to crisis situations. These critical industries have been subjected to scientific research, which showed that they have more crisis experience, i.e. they more often go through image crises. Thanks to this, managers representing companies operating in this industry are more aware and better prepared for possible image crises. Business entities classified as oppressive industries are normally more susceptible to crisis situations. This type of enterprises need to be aware of this fact and prepared for image-related problems. Classifying industry as oppressive seems to be well-grounded due to such factors as susceptibility of entities operating within the industry to external factors, the complexity of processes performed in the process of production and rendering services, as well as the ultimate consumer's complicity in those processes. The image crisis involves not only negative implications, but also positive effects - it can be considered as an industry's immune system which gains strength every time a crisis is properly managed.
\end{abstract}

Keywords: image crisis, economic crisis, oppressive industries

\section{IMAGE CRISIS - DEFINITION AND CONSEQUENCES}

The concept of crisis - normally more often than that of image - can be found in different categories such as economy in particular. Due to the so-called cycle, the economy is subject to crises as much as to periods of growth and boom. Economic crisis is characterized by a set of disturbances, as a result of which the economy and the business entities that function within it are exposed to a number of problems reflected in many parameters, such as unemployment, inflation or investments. Terminologically speaking, an economic crisis is far from an image crisis; however, they are similar when it comes to cause and effect, and both of them require proper analysis and prediction (Tworzydło, 2017). Economic crisis can be considered in terms of micro- and macro-scale. The latter is closely connected to business management and the linkage between image crisis and economic crisis is to be seen particularly in this respect. The latter results from the former and conversely, as one of them occurs, then the chances of the other happening are very high. This paper, however,

\footnotetext{
${ }^{1}$ Dariusz Tworzydło, DSc PhD, University of Warsaw, The Faculty of Journalism, Information and Book Studies, Bednarska 2/4, 00-310 Warsaw, Poland. ORCID: 0000-0001-6396-6927.

2 Norbert Życzyński, PhD, Rzeszow University of Technology, The Faculty of Management, Department of Management Systems and Logistics, Akademicka 2, 35-084 Rzeszów, Poland, E-mail: n.zyczynski@prz.edu.pl. ORCID: 0000-0003-0681-3072.
} 
focuses primarily on the analysis of an image crisis. It can be defined as a situation characterized by extraordinary sensitivity to external factors (outside of the industry) as well as internal factors (within the industry). It refers to every situation which threatens the stability of a business entity (Łaszyn, 2011). It is a state during which the normal functioning of an industry is disturbed. Instead, actions taken with the aim of preventing and overcoming the already existing as well as potential consequences and difficulties of the crisis are given priority. A crisis situation is also construed as a period of time in which the effective execution of the mission and the achievement of goals established by an organization, a brand or public official are put at risk, with the image crisis as the climax of the situation (Kaczmarek-Śliwińska, 2015). For every element of an industry's structure, the crisis is somewhat of a test. Disorders in the external and internal communication as well as the loss of credibility or trust (which is one of an industry's most significant assets) are among the gravest consequences of the crisis. Apart from these, the crisis also affects a company's economic performance results, i.e. a fall in sales, loss of market, loss of customers, contractors, suppliers and subcontractors, employee resignation (increased staff turnover), and inventory increase. Image crisis does not, however, carry only negative consequences. It can also involve positive outcomes, which are part and parcel of the phenomenon. For a business, a crisis is a test which verifies the procedures and the resilience of its structures. The crisis also involves an assessment of the developments and routines within a business, such as all the procedures and the extent to which the staff is prepared to manage the problems. Therefore, it can be perceived as an assessment on the one hand and, on the other hand, a process of collecting information and additional experience, this time on the living organism (Tworzydło, 2017).While discussing the problem of image crisis situations, the types of crises that can affect a business cannot be omitted. Topic-related literature offers vast classifications; however, one of them is worth indicating in this paper. In Coombs' Crisis Matrix, four types of crisis are analysed in two dimensions: internal and external. The author also points to the fact that one is dealing here with unintentional and deliberate actions (Table 1). The emphasis must be placed on the internal dimension, which is not only the first and the key one in the context of providing information concerning the existing risks, but it is also where the crisis situation occurs. These are generated mostly by employees or while the production and service processes are carried out. In this instance, both deliberate and unintentional action is relevant. The former includes intentional action taken by the employees. These are influenced by emotions or dissatisfaction, or simply a desire to take revenge on the employer. The latter are mostly caused by mistakes in procedures. Although the tool proposed by Coombs offers a general description of types of crisis situations, the Crisis Matrix provides help in preparing an effective strategy of crisis communication.

Table 1. Crisis Matrix (Coombs, 1995)

\begin{tabular}{|c|c|c|}
\hline & Unintentional & Intentional \\
\hline External & Faux Pas & Terrorism \\
\hline Internal & Accidents & Transgressions \\
\hline
\end{tabular}

It is indicated by Coombs that identifying the type of crisis is one of the key ingredients of professional management in a problematic image situation, in which the following actions include specific steps directed at the media or other groups with a vested interest. In 
the processes discussed in this paper, two other concepts are also particularly important. The first one, anti-crisis management, can be defined as actions taken before the crisis itself occurs, whereas the second one, crisis management, is understood as the steps taken when the crisis has already taken place in a company, once it has escalated and has manifested itself in consequent symptoms (Tworzydło, 2017). Both concepts are equally important in the whole process and are closely linked to each other, since proper preparation for potential crisis situations affects the management of the crisis once it has taken place. Preparation, however, plays a vital role because it secures the industry. It can be construed as its immune system which can either counter any potential attacks directed at the industry's image, or manage the problems once they have occurred, with as little strain and complication as might be. Preparation is thus closely connected to the notion of security which, admittedly, cannot be a guarantee for an industry, but it supports it and limits any potential consequences.

\section{FACTORS AFFECTING THE OCCURRENCE OF A CRISIS SITUATION}

Preparation for an image crisis situation involves determining the factors that, to a greater or lesser extent, affect the occurrence of the crisis. In particular, defining the industry category is one of the factors, as it has a strong influence on both potential and real risks. The first degree of vulnerability indicates that the company is least exposed to a crisis of a reputational nature. Image problems may worsen the image of the company, however, only in the event of incorrect reactions that would be the company's fault, but here it should also be noted that this will rather have little impact. Unless there are serious critical errors made by the company during the crisis. The second degree of vulnerability indicates that the company already have been in crisis situations and had to deal with them. However, these events still had little impact on the overall perception of the company. It is only at the third degree that the crisis has a major impact on the perception and image of the company. Within the diagnostic model, the fourth degree of crisis susceptibility indicates that in businesses that operate as the so-called oppressive industries, the occurrence and aggravation of crisis situations is more likely than in other industries. What follows, such businesses are also more exposed to the consequences of the ensuing problems. What is more, the fourth degree of crisis susceptibility shows that a business entity that is perceived as belonging to these categories is incapable of a legitimate response once a crisis situation has occurred or experiences too much strain due to the fact that it operates within an oppressive industry (Table 2).

As far as the analysis of potential changes in an industry in the context of crisis susceptibility is concerned, it must be said that an oppressive industry can be described in terms of the fourth degree, but business entities that fall into the third degree of crisis susceptibility can also operate within an oppressive industry. A similar situation takes place in other cases. The fact that a company falls into the category of an oppressive industry does not necessarily mean that it always qualifies as the fourth degree of crisis susceptibility; however, the fact that such a company is at risk of an image crisis is beyond any doubt. Classifying an industry as oppressive does not imply an immediate change of the company's category from - for instance - the second to the third degree of crisis susceptibility. This is because such a situation is strongly influenced by the actions taken by a business in order to prepare for and react to the crisis. All in all, the oppressive character of an industry is an important element affecting the calculations made within the diagnostics model, which helps to assess 
Table 2. An analysis of potential changes in an organization in the context of degrees of crisis susceptibility (Tworzydło, Szuba, 2018)

\begin{tabular}{|l|l|l|l|l|}
\hline & $\mathrm{I}^{\circ}$ & $\mathrm{II}^{\circ}$ & $\mathrm{III}^{\circ}$ & $\mathrm{IV}^{\circ}$ \\
\hline the ability to absorb a consequent crisis & small & small & big & big \\
\hline the influence of a subsequent crisis on employees & small & small & big & big \\
\hline $\begin{array}{l}\text { the influence of the crisis on the industry's economic } \\
\text { conditions }\end{array}$ & none & none & big & big \\
\hline $\begin{array}{l}\text { the influence of the crisis on the perception of the busi- } \\
\text { ness }\end{array}$ & none & small & big & big \\
\hline $\begin{array}{l}\text { the influence of the crisis on the internal business envi- } \\
\text { ronment }\end{array}$ & none & small & small & big \\
\hline restricting the company's strategic possibilities & none & none & small & big \\
\hline restricting the company's operational possibilities & small & small & big & big \\
\hline the influence on controlling subsequent crisis situations & big & big & small & none \\
\hline $\begin{array}{l}\text { the possibility of alleviating the consequences of the } \\
\text { crisis }\end{array}$ & big & big & small & small \\
\hline the possibility of obtaining positive results of the crisis & big & big & small & none \\
\hline the cost of anti-crisis actions & small & small & big & big \\
\hline the media's trust during the crisis & big & small & small & none \\
\hline
\end{tabular}

correctly to what extent a business entity is prepared for a crisis situation. An oppressive industry is one in which the entities constituting it are at a particular risk of image crisis situations and, at the same time, experience an increased susceptibility to the crises and their occurrence frequency (Tworzydło, Szuba, 2018). Below are selected conditions that classify a business as an oppressive industry:

- the industry consists of entities that operate within the areas in which an individual consumer is the main receiver of products or services; therefore, business entities belonging to B2B industries face a smaller risk of oppressiveness that $\mathrm{B} 2 \mathrm{C}$,

- goods and services offered by businesses within the industry have a short durability period or have a significant influence on the average person's life,

- a range of production and service processes take place in complicity with target consumers, who participate in the whole process to a significant extent and have an influence on the final product or service that they purchase,

- the production or the process of rendering services bears the risk of an accident that can occur within the process itself or once the product has already been serviced,

- the production of services or goods has a complicated character and consists of a number of processes, and is contingent on independent factors which are beyond the industry's control, such as weather conditions,

- various business entities within the industry compete with each other, and the character of such competition is not always fair or might involve methods which are considered to be unethical.

Obviously, for an industry - and the businesses operating within it - the conditions listed above do not have to be met simultaneously to classify it as oppressive within the category of image crisis susceptibility. However, they serve as a kind of a determinant which helps 
to assess correctly whether a given industry can be classified as susceptible to the crisis. An oppressive industry is also one in which various business entities experience external (e.g. from the media) or internal pressure (e.g. from trade unions), which, in turn, may translate to potentially turbulent relations with the representatives of those environments. Taking Polish Classification of Activities into consideration, a number of businesses that meet the criteria of an oppressive industry can be distinguished. These include industries such as (Tworzydło, Szuba, 2018):

- food,

- extraction,

- construction,

- transport,

- automotive,

- development,

- fuel,

- energy,

- chemical,

- pharmaceutical,

- railway,

- telecommunications,

- financial,

- insurance,

- FMCG,

- road infrastructure

- and others.

The industries indicated above do not exhaust the list of those which satisfy the conditions ascribed to oppressive industries; nevertheless, they the main ones and the most exposed to image crisis situations.

\section{THE TEXTILE INDUSTRY AS AN EXAMPLE OF OPPRESSIVE INDUSTRY}

The textile industry is one of the industries that can be characterized as oppressive. Despite the fact that it is not on the list of oppressive industries, the textile industry can be included in it due to a number of factors that distinguish it based on further analysis. The aim of the assumption is, therefore, to show that there are also a number of other industries outside the indicated list, which may be burdened with the risk related to the oppressiveness of the industry.

The problem of a potential crisis which may affect the processes of production and the overall functioning of a business entity, appears when there is a connection between a customer's expectations and the process of production. In the situation discussed here, the buyers have a significant influence on the eventual shape of the product they purchase and at the same time have specific requirements concerning its quality as well as other expectations, such as those connected with the product's seasonality. The textile industry is highly dependent on the customer's preferences and expectations, for whom criteria such as variety, change, and adjustments to trends acquire increased significance. Also, availability is yet another parameter that is particularly important to the customer, and it's closely connected to the location of the shop. Having said that, responding to changing trends, adjusting 
to them, and - most of all - gathering information with the aim of securing the industry in case a crisis occurs - is one of the primary purposes of business entities operating within the textile industry. In this industry, the correlation between economic and image crisis acquires a special meaning, since both of them have a strong influence on one another. The way in which economic crisis affects image crisis is particularly visible. Knowing that economic crisis can be caused and aggravated by the changes that happen to the entity's image, the correlation between the factors that have an impact on the image and the ones that are strongly connected to economic parameters can be observed quite easily. The textile branch is characterized by an increased sensitivity to the factors shaping the demand. These factors exist outside of the price, which is the main determinant according to the theory of economy and more specifically, the law of demand. Instead, the factors in question are linked to designing and creating trends and fashion. One of the elements included in the prevention of crises resulting from the lack of sufficient information for customers and disrupted information flow, is providing a transparent supply chain in the context of its managements and functioning. It is claimed sometimes that this constitutes one of the key challenges that contemporary logistics face. For that reason, effective management of a contemporary supply chain requires, for instance, automation of processes and access to real-time data (Bujak, 2015).

All of these also translated into the image of particular business entities operating within the textile industry. Since a detailed analysis as well as determining the parameters that define the textile industry imply that it can be classified as a so-called oppressive industry, it must be noticed that the textile industry is characterized by an increased susceptibility to image crisis situations, a tendency to absorb them easily and a vulnerability to subsequent crises. Image crisis affecting businesses which operate within oppressive industries is more intense and more critical as far as selected or - even all aspects of the company's management and organizational structure. Hence, the issue of securing the entities in question becomes essential. The classification of the textile industry as an oppressive industry results from the fact that such industries are mostly connected to the areas in which there is a number or individual customer, each of whom can perceive the services provided by a given business entity differently, which is the case in the textile industry. An analysis of oppressive industries looks for interrelations in which the probability of mistakes, failures or problems related to the service of the products produced is increased due to the scale of production. Other conditions that classify the textile industry as an oppressive industry include intense changes in production, ranging from technological processes to generating the final product which is adjusted to customers' expectations, as well as changes in customers' requirements, changes in those requirements, the need to respond to changing trends and fashion, the development of information technology affecting the process of communication with customers, and advancing from traditional sale to on-line sale. Oppressive industries are particularly characterized by increased vulnerability to crisis situations. Therefore, business entities involved in them face the necessity of taking actions not only before or during but also once the crisis has died out. Once the problems have disappeared and their implications have been largely erased, a complete post-crisis record must be prepared. It is essential not only due to the analysis of the situation that is now gone but, most of all, for the sake of obtaining valuable information for the future. It is also useful in litigation and prolonged legal proceedings such as legal disputes connected with the media having given false information affecting the scale of the crisis. What is more, formu- 
lating a protocol has an influence on changing the procedures, making corrections and developing proper trainings for the employees. A set of analyses produced during and after the crisis situation is dedicated not only to the management of the business but also to the crisis management center and to those individuals who might be, either directly or indirectly, interested in benefiting from the knowledge and experience gathered during the image crisis (Rydzak, 2006).As far as managing a future crisis is concerned, the success rate is dependent on a number of conditions. These include the extent to which a business is susceptible to crisis, the situations it had experienced before, whether it is classified as an oppressive industry, whether it has a crisis management centre, the level of the management's awareness of image risks, the attitudes towards the crisis in the business, and once it has been erased, the way in which its causes and its effects are analysed.

\section{CONCLUSION}

Business entities classified as oppressive industries are normally much more susceptible to crisis situations. The businesses in question need to be aware of this fact and prepared for image-related problems. Companies operating within oppressive industries may themselves cause crises through their actions; therefore, proper preparation should be inscribed in their standards of management (Tworzydło, Szuba, 2018). In this way - since the entities constituting the textile industry may be classified as those constituting an oppressive industry - not only preparation, but also constant monitoring, analysis, and fast action once a crisis situation has occurred are necessary. These actions can be taken with the aid of a number of research strategies, as well as methods which allow real-time monitoring of the situation. It must be pointed out that there are also methods which enable determining specific factors affecting a company's image and its potential deterioration. One of such methods is, for instance, is a matrix of image purposes, which makes it possible to identify the areas and courses of action supporting an organization (Tworzydło, Życzyński, 2008). Classifying the textile industry as one that can be described as oppressive seems to be well-grounded due to such factors as: susceptibility of entities operating within the industry to external factors, the complexity of processes performed in the process of production and rendering services, as well as the ultimate consumer's complicity in those processes. Undoubtedly, the crisis poses a threat to a company and involves both direct and indirect influence on its structures as well as on the relations in the company and outside of the company. However, it can also be perceived as a chance for the business. In this respect, the awareness and knowledge concerning the fact that a business operates within an oppressive industry can affect the whole process, strengthen it and contribute to overcoming the difficulties that the business experiences. The level of awareness and the way in which knowledge is used translate not only into the economic situation, but also into parameters which are more difficult to measure, such as image, perception, and trust. The awareness of the fact that a company operates within an oppressive industry is important; however, it is not enough as far as successful management of the crisis is concerned. In order to achieve this goal, proper procedures, descriptions of processes, appointing a crisis management centre and preparing the operational documentation that can be used in the simulation of a crisis situation are also necessary. To sum up, it is worth indicating that image crisis involves not only negative implications, but also positive effects. This, however, refers not only to businesses classified as oppressive industries, but rather to all businesses. Preparation and skilful management of the crisis translates into the net effect, i.e. reinforcement of the business 
structures and all of the parameters that affect its rating. Strangely enough, the conclusion might thus be that image crisis is a positive phenomenon, since it can be considered an industry's immune system which gains strength every time a crisis is properly managed.

\section{REFERENCES}

Bujak, A. (2015). Zarzadzanie i funkcjonowanie wspótczesnego i perspektywicznego łańcucha dostaw. „Studia Ekonomiczne. Zeszyty Naukowe Uniwersytetu Ekonomicznego w Katowicach” nr 249.

Coombs, T.W. (1995). Choosing the right words: The development of guidelines for the selection of the appropriate crisis-response strategies. "Management Communication Quarterly" 8(4).

Kaczmarek-Śliwińska, M. (2015). Public relations $w$ zarządzaniu sytuacjami kryzysowymi organizacji. Sztuka komunikowania się. Warszawa: Difin.

Łaszyn, A. (2011). Komunikacja kryzysowa [w:] Sztuka public relations. Z doświadczeń polskich praktyków. Wyd. 2. Warszawa: Związek Firm Public Relations.

Rydzak, W. (2006). Zarzadzanie informacja w sytuacjach kryzysowych [w:] Tworzydło, D., Olędzki, J., red., Public relations znaczenie społeczne $i$ kierunki rozwoju. PWN, Warszawa: PWN.

Tworzydło, D. (2017). Public relations praktycznie. Rzeszów: Wydawnictwo Newsline.

Tworzydło D., Życzyński N. (2008). Metoda sferyczna i płaszczyznowa obliczania luki wizerunkowej [w:] Tworzydło, D., Chmielewski, Z., Public relations $w$ czasach mp3 oraz Internetu. Rzeszów: Wyższa Szkoła Informatyki i Zarządzania.

Tworzydło D. (2017). Procedura zarzadzania $w$ kryzysie wizerunkowym $w$ mediach - przeciwdziałanie, reagowanie oraz odzyskiwanie utraconych korzyści. „Studia Medioznawcze” nr 3 (70).

DOI: $10.7862 /$ rz.2019.hss.10

The text was submitted to the editorial office: June 2018.

The text was accepted for publication: March 2019. 